\title{
SOUTH AFRICAN TEACHERS' MATHEMATICAL KNOWLEDGE: REFLECTIONS FROM SHORT LEARNING INTERVENTION PROGRAMME (SLIP)
}

\author{
Loyiso C. Jita, Olugbenga Adedayo Ige \\ University of the Free State, Republic of South Africa \\ E-mail: jitalc@ufs.ac.za, IgeOA@ufs.ac.za
}

\begin{abstract}
This qualitative research reports the results of a short learning intervention programme conducted by South African National Roads Agency Limited (SANRAL) Chair in Science and Mathematics Education to enhance the mathematical knowledge of teachers in some South African schools. The short learning programme comprised the fostering of teachers' mathematical knowledge and the formation of lesson study groups to apply the knowledge gained from the intervention programme in different schools in the country. The sample comprised 53 male and 72 female Mathematics teachers who were nominated from several school districts in the country. The participants were trained using Mathematical Knowledge for Teaching (MKT) which included the topics of probability/ratio and proportion (grades 1-9). The MKT consisted of these sets of expertise: Common Content Knowledge (CCK), Specialised Content Knowledge (SCK), Knowledge of Contents and Students (KCS), and Knowledge of Content and Teaching (KCT). The lesson study groups applied the knowledge acquired from the short learning intervention programme to engage in group activities, lesson studies, and to report the major challenges in doing the lesson studies. This model research comprised three stages: the first stage involved active participation in the workshops that took place at the University of the Free State; the teachers that attended the training workshops implemented the knowledge gained in the respective schools in their districts in the second stage; and the third stage involved the compilation and submission of a Portfolio of Evidence (PoE) by the teachers that participated in the training workshops.
\end{abstract}

Keywords: mathematical knowledge, short learning intervention programme, South African teachers.

\section{Introduction}

This research documents the experiences and breakthroughs of Mathematics teachers working in South Africa. The teachers that participated in this study received a short learning workshop from the South African National Roads Agency Limited (SANRAL) Chair in Science and Mathematics Education at the University of the Free State, South Africa. The article presents the training experiences of the teachers and the improvement it brought to their mathematical knowledge. As recently as 2014, a notable study (Jita \& Mokhele) projects the importance of different programmes aimed at developing teachers professionally in the nooks and crannies of the world. This development came at a time the disappointing performance of South African school children in Science and Mathematics in Trends in International Mathematics Education (TIMSS) needed urgent attention from academic researchers. Jita and Mokhele (2014) believed that building the capacity of the teachers is the end that any ongoing professional development such as the SANRAL Chair in science and Mathematics Education is designed to achieve. 
Loyiso C. JITA, Olugbenga Adedayo IGE. South African teachers' mathematical knowledge: Reflections from short learning intervention programme (SLIP)

PROBLEMS

OF EDUCATION

IN THE $21^{\text {st }}$ CENTURY

Vol. 77, No. 6,2019

706

\section{Need for an Intervention Programme for South African Teachers on Mathematical Knowledge}

The short learning intervention programme is founded on scholars' belief that the most veritable channel of improving learning outcomes is to improve instructional delivery (Labuschagne, 2016; Taylor, 2008). Evidences from the research of Venkat and Spaull (2015) showed that inadequate fundamental understanding of mathematical concepts by South African teachers is responsible for the poor performance of learners' in Mathematics in South African Schools (p. 121). The disappointing performance of South African children in TIMSS justified the need for the short learning intervention programme. Furthermore, Reddy et al. (2012) noted that South Africa, Botswana, and Honduras had low performance in TIMSS in 2011. These countries whose Grade 9 learners were assessed were among the six countries that were rated below the least achieved benchmark in Science and Mathematics. It is consequent on this unfavourable performance that the short learning intervention programme was put together to enrich the mathematical knowledge of teachers in South Africa.

The purpose of the short learning intervention was twofold: first, to foster teacher's mathematical knowledge in South Africa; second, to set up lesson study groups that will apply the knowledge acquired from the programme in South African schools. The programme was designed with focus on two major objectives; to overcome teachers' knowledge deficit in mathematical concepts that hinders empirically sound classroom practices, and to use strategies (i.e. teachers' cluster) that are research-driven to train teachers with ample teaching experience in Mathematics. In view of this, the theoretical framework that is relevant to teachers' professional development is reviewed and presented an overview of the activities of SANRAL Chair in Science and Mathematics Education. Finally, the nitty-gritty of the short learning intervention programme is outlined, the research questions presented, and the results of the preliminary exploration are given.

\section{Theory of Peer Observation Process}

The short learning intervention programme is underpinned by the model of the peer observation process developed by Bell (2002). Different scholars have demonstrated that peer observation is an effective tool to enhance teaching outcomes and experience (Bell, 2001; McGrath, 2016). The model evolved by Bell (2002) is cyclical in nature and is diagrammatically presented in Figure 1.

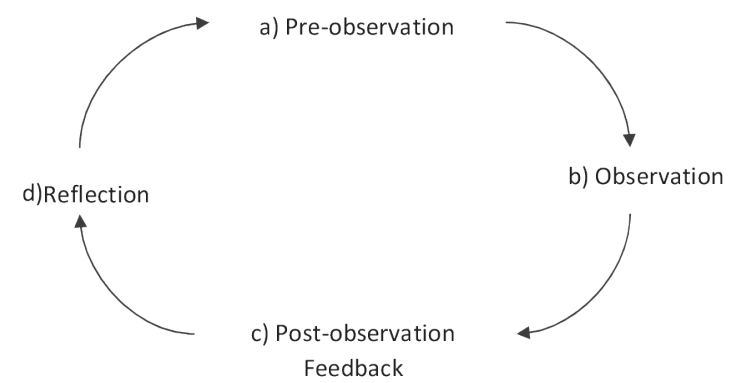

Figure 1. Peer observation process (Bell 2002).

The model is sub-divided into the following stages: pre-observation, observation, postobservation feedback, and reflection. Despite the benefits inherent in the peer observation process, Thomson, Bell and Hendry (2015) cautioned educational researchers on the inactivity related to peer observation process such as the procedural and documentation aspects of teaching 
Loyiso C. JITA, Olugbenga Adedayo IGE. South African teachers' mathematical knowledge: Reflections from short learning intervention programme (SLIP)

development. These inadequacies notwithstanding, Shulman (2000) argued that the scholarship of teaching is developed when teachers' work is peer-reviewed, critiqued and shared with other colleagues in their professional communities (as cited in Engin, 2016, p.379).

The pre-observation stage of the peer observation process involves the discussion of learning objectives and setting of ground rules for the observation (see Rees, Davies, \& Eatwood, 2015, p.269). The observation stage is the primary focus of the peer observation process. Hendry and Oliver (2002) stated that this stage is focused on helping teaching colleagues to develop their teaching acumen. Martin and Double (1998) affirmed that the observing teacher is involved in the experience without interfering in the dialogue and intellectual debates going on in the classroom. Martin and Double (1998) proposed that the observing teachers should adopt a systematic approach to taking observation notes in order to enable the active intermittent teacher to note the contours of the teaching session. The post-observation stage is concerned with the provision of an honest and constructive report from the observing teacher to the active teacher. Rees et al. (2015) stated that the observing teacher is expected to trigger the goals for personal development in the observed teacher (i.e. Tutor). It is expected that the goals for personal development will provide the basis for the observed teacher to reflect.

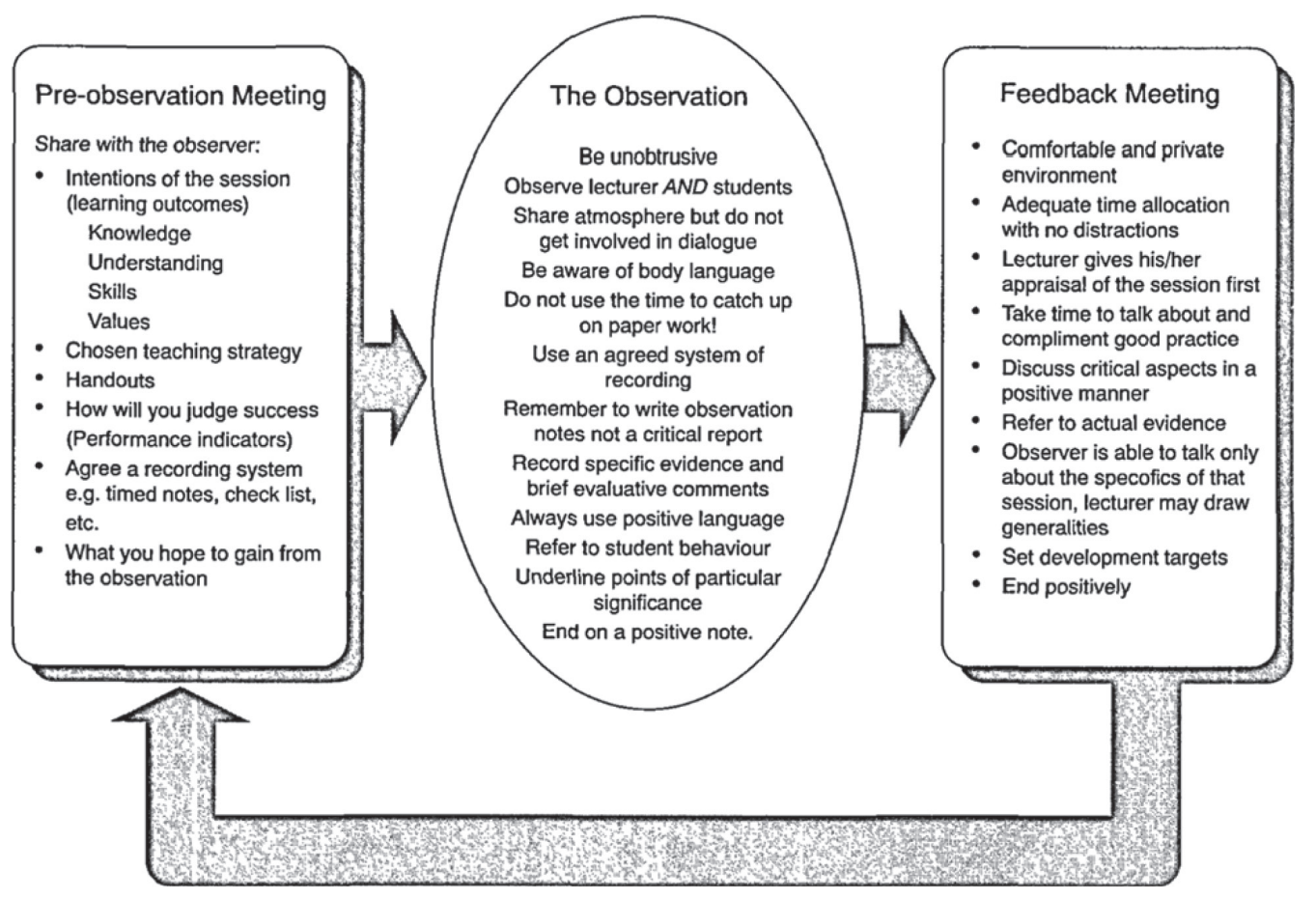

Figure 2. Peer observation process model.

The Short Learning Intervention Programme reported in this research is founded on the peer observation process developed by Bell (2002) in Martin and Double (1998, p.165). Some of the elements of the intervention programme are also closely related with the contents of Shulman's model of pedagogical reasoning and action, which stressed an open and flexible basis for handling the nexus between content and instructional delivery or strategies (see Shulman (1986; 1987), using Shulman's model of pedagogical reasoning and action in a preservice programme. To this end, the researchers sought to answer these questions:

1. What are the pre-observational activities of the selected teachers after undergoing the short learning intervention programme?

$\mid \begin{aligned} & \text { PROBLEMS } \\ & \text { OF EDUCATION } \\ & \text { IN THE } 21^{\text {st }} \text { CENTURY } \\ & \text { Vol. } 77, \text { No. } 6,2019\end{aligned}$

707 
Loyiso C. JITA, Olugbenga Adedayo IGE. South African teachers' mathematical knowledge: Reflections from short learning intervention programme (SLIP)

PROBLEMS

OF EDUCATION IN THE $21^{\text {st }}$ CENTURY Vol. 77, No. 6, 2019

708

2. What are the observational activities of the selected teachers after undergoing the short learning intervention programme?

3. What are the feedbacks from the observing teachers to the active teachers after applying the knowledge acquired from the short learning intervention programme in their lessons (Post Observation Reflection)?

\section{Research Methodology}

\section{Research Design}

The research used the after-the-fact research design of a qualitative type. The data were taken from the 'portfolio of evidence' submitted by the teachers who partook in the short learning intervention programme to the SANRAL Chair in Science and Mathematics research office. The research focused on mathematics teachers at different grade levels in South Africa. The duration of the research activities was three months. The training workshops took place on 15-16 November 2013, 7-8 February 2014, and 7-8 March 2014. The completed portfolios were submitted by the teachers that participated in the intervention programme to the 20 March 2014.

\section{Population and Sample}

The population consisted of Mathematics teachers in public schools in Free State, South Africa. There are 26,000 public schools in South Africa, 1255 of these schools are located in Free State province (Free State Department of Education, 2017). 125 Mathematics teachers from 60 of the 1255 schools in rural and urban locations in Free State province were nominated by the School Management Teams through the Free State Department of Education to participate in the programme. 72(57.6\%) of the teachers were female, while $53(42.4 \%)$ were male. These teachers taught Mathematics to grades 1 to 9 pupils in their various schools and were nominated by the management of their respective schools for the research.

\section{The Short Learning Intervention Programme (SLIP)}

The SLIP was designed to improve teachers' mathematical knowledge for teaching (MKT), the topics of probability or ratio and proportion in grades 1 to 9 in South African schools. The MKT included Common Content Knowledge (CCK), Specialised Content Knowledge (SCK), Knowledge of Contents and Students (KCS), and Knowledge of Content and Teaching (KCT). All teachers that participated in the study signed a binding contract with their schools of affiliation to complete the programme.

The SLIP was made up of training phases which comprised professional development workshops for the selected teachers, individual tasks, collaborative tasks, and group presentations on mathematical problems solved during the workshops. The implementation phase of the SLIP consisted of: Teachers' formation of an active lesson study group which comprised 3-10 members per group, collaborative lesson planning among members of the lesson study group. A minimum of 3 lesson plans were required. Lesson presentations which involved the presentation of a minimum of 3 lessons by the study groups. Members of the lesson study groups mutually observed the lesson of each other and submitted their observations. These observations were discussed among members of the group.

The teachers recorded and submitted evidence of participating in each of the different components of the lesson study with their group members. These evidences included pictures, videos, and audio and were put in a report form and signed by the principals of the schools the teachers in the lesson study group were affiliated to. The teachers submitted the 'Portfolio of 
Loyiso C. JITA, Olugbenga Adedayo IGE. South African teachers' mathematical knowledge: Reflections from short learning intervention programme (SLIP)

Evidence (PoE)' to the SANRAL Chair in Science and Mathematics and reported again to the principals and/or school management team where required.

\section{Instruments}

An instrument tagged 'Lesson Study: individual Report was developed by SANRAL Chair in Science and Mathematics Education. The LSIR was constructed in line with stages of Bell (2002)'s peer observation model. These stages are pre-observation, post-observation feedback, and reflection. The LSIR has the following sections: setting up the lesson study groups; group activities, lesson study and challenges and opportunities (See Appendix 1).

Another instrument that was used in this research was the 'Mathematical Knowledge for Teaching UFS Short Learning Programme (MKTUSLP)'. This outline describes the nitty-gritty of the SLIP, and other expected outcomes for the trainees that participated in the research. Section 1 of the outline provides information on the sponsor of SLIP, section 2 highlights the expectations of the service provider from participating teachers such as commitment and responsibility, active participation during workshops, and implementation of workshops in schools the teachers are affiliated to. Section 3 of this outline covers the administration and logistics regarding the participation of teachers during the learning workshops that were held at the University of the Free State (See Appendix 2).

\section{Credibility and Trustworthiness}

The instruments used to collect data in this study were designed by a Professor of Mathematics Education at the University of the Free State. The Professor has taught and conducted research on Mathematics education for more than twenty years. The LSIR and MKTUSLP were made available to officials of the Free State Department of Education (FSDoE), Education, Training and Development Practices Sector Education and Training Authority (ETDP-SETA) for their assessment and comments. These officials of the government were brought in to ascertain if indeed the contents of the instruments were in line with best practices for teachers' professional development in Mathematics Education as stipulated in government policy documents. Their comments and observations were used to improve the research instruments.

\section{Data Collection}

Each teacher that applied the knowledge gained from the short learning intervention programme in his/her school used the LSIR to create an individual report. Each Mathematics teacher created a portfolio of evidence with his/her report and submitted to the Research Office of SANRAL Chair in Science and Mathematics Education at the University of the Free State. The data for the study were gotten from the portfolio of evidence submitted by the teachers that participated in the intervention and these were collected from the Research Office of the SANRAL Chair in Science and Mathematics Education.

\section{Procedure}

The research was divided into four phases (see Rossi \& Stuart, 2007, p.141), namely:

- the development of short learning intervention programme by the SANRAL Chair in Science and Mathematics Education,

- the implementation/use of the short learning intervention programme to train Mathematics teachers, 
Loyiso C. JITA, Olugbenga Adedayo IGE. South African teachers' mathematical knowledge: Reflections from short learning intervention programme (SLIP)

PROBLEMS

OF EDUCATION

IN THE $21^{\text {st }}$ CENTURY

Vol. 77, No. 6,2019

710

- the application of the knowledge acquired from the short learning intervention programme to teach Mathematics lessons in the benefitting teachers' school,

- and submission of a Portfolio of Evidence on the impact of the short learning intervention programme to the SANRAL Chair in Science and Mathematics Education at the University of the Free State, South Africa.

- The short learning intervention programme took place from 15 November 2013 to 20 March 2014. The learning workshops component of the SLIP took place on 15-16 November 2013, 7-8 February 2014, and 7-8 March 2014. The teachers concurrently implemented the new knowledge gained from these training workshops in their respective host schools. All the Portfolios of Evidence (PoE) were submitted on or before 20 March 2014.

\section{Integrated Quality Management System}

These steps outline how the teachers that participated in the study implemented the short learning intervention programme:

(Implementation of the Short Learning Intervention Programme by Mathematics Teachers)

1. The teachers' convened a meeting in the Principal's Office with a proposed agenda tagged 'information on Lesson Study'.

2. The teachers that have benefitted from the short Learning Intervention Programme formed an active lesson study group consisting of 4-10 members.

3. The teachers exhaustively discussed strategies to teach the mathematical concept of Probability (Grades 1-9) or Ratio and Proportion (Grades 1-9) which were the focus of the short learning intervention programme.

4. The teachers collaborated to create teaching materials that would enable students to effectively learn the selected mathematical concepts (i.e. Probability or Ratio and Proportion).

5. The teachers convened another meeting at the Principal's Office to collaboratively prepare three lesson plans to teach the selected mathematical concepts.

6. Teachers in the group presented the lessons one after the other on a daily or weekly basis while the other teachers in the group observed and wrote such in the teaching observation forms.

7. Each lesson presented by the teachers that taught the selected concept lasted for one hour.

8. The observing teachers gave a constructive feedback to the teacher that taught the concepts one after the other.

9. The teachers collaboratively prepared a portfolio of evidence containing different components of a lesson study (i.e. minutes of mention)

10. The teachers submitted the portfolio of evidence created to the SANRAL Chair in Science and Mathematics Education.

\section{Ethical Scrutiny}

The ethical blueprints of the host university were stringently followed, while SANRAL Chair in Science, Mathematics, and Technology obtained permission from the Free State Department of Education (FSDoE) to train the selected mathematics teachers. The researchers further collected informed consent from the teachers and made avenues for them to disengage at any point during the research. However, the selected teachers signed a contract with the nominating schools to complete the training programme before they can train other mathematics teachers with the knowledge acquired from this research in their schools. 
Loyiso C. JITA, Olugbenga Adedayo IGE. South African teachers' mathematical knowledge: Reflections from short learning intervention programme (SLIP)

\section{Data Analysis}

The data put together by the participants in the 'Portfolio of Evidence' which was presented in line with the reporting format provided by SANRAL Chair in Science, Mathematics, and Technology. These 'Portfolios of Evidence' were analysed to identify the patterns of participants' responses and observations in line with the format of the individual reports (i.e. setting up the lesson study groups, group activities, lesson study, and challenges and opportunities). The constant comparison technique developed by Glasser and Strauss (1967) was used to open code the data in an initial code list until analysis had reached theoretical saturation. The discussion section highlighted the themes that characterised the data submitted in 'Portfolios of Evidence' by the mathematics teachers that participated in the short learning intervention programme.

\section{Research Results}

To ascertain how the participants used the knowledge benefitted from the short learning Intervention Programme to teach the mathematical concepts of probability or ratio and proportion, the korero (i.e. discussion or meeting) was thematically triaged along preobservational activities and feedback from the observing teachers. By repeatedly comparing the contents of each pre-observation preparation from what was included in the portfolio of evidence by the group of teachers, the elemental theme of pre-observational activities that emerged is 'clustered' lesson plan preparation.

The excerpts below confirm the 'clustered' lesson planning that evolved from the interactions of the participants after the intervention programme.

Table 1. Excerpts of clustered lesson planning.

\begin{tabular}{|c|c|}
\hline DATE & 27 February 2014 \\
\hline Place/School & Nthapelleng Intermediate School \\
\hline Time & $13: 30$ (40 minutes) \\
\hline Group Facilitator/Leader (+ contact details) & Kyman N.D 0842593280 \\
\hline Planning Team (all teachers in the group) & $\begin{array}{l}\text { Kynman NT Kesebo TJ, Pkhlabi TM, Ramoshane DJ, } \\
\text { Ekhulergeni JM }\end{array}$ \\
\hline Topic Selected & Probability: Tossing a coin \\
\hline $\begin{array}{l}\text { Learner Prior: Knowledge (Key ideas only) (content to be } \\
\text { covered) (key ideas only) }\end{array}$ & $\begin{array}{l}\text { Simple experiment } \\
\text { Tallies } \\
\text { Perform simple experiments } \\
\text { List outcomes based on the conditions of the activity } \\
\text { Determine probability of possible outcomes }\end{array}$ \\
\hline Intended Outcomes of the lesson & $\begin{array}{l}\text { Compare relative frequency and probability } \\
\text { List and predict outcomes } \\
\text { Conduct probability experiments }\end{array}$ \\
\hline Resources to be used during the lesson & $\begin{array}{l}\text { Textbook } \\
\text { Coin } \\
\text { Chalkboard }\end{array}$ \\
\hline $\begin{array}{l}\text { Lesson activities (what will the learners do? What will the } \\
\text { teacher do?) }\end{array}$ & $\begin{array}{l}\text { Teacher introduces the lesson; } \\
\text { Explaining keywords; show learners examples. } \\
\text { Learners toss coin, record the outcomes in a tally table } \\
\text { and find the frequency }\end{array}$ \\
\hline $\begin{array}{l}\text { Advisor (any external invited participants supporter: } \\
\text { principal/Deputy Principal (Signature and Stamp)) }\end{array}$ & Mr. Khema \\
\hline
\end{tabular}


Loyiso C. JITA, Olugbenga Adedayo IGE. South African teachers' mathematical knowledge: Reflections from short learning intervention programme (SLIP)

PROBLEMS

OF EDUCATION

IN THE $21^{\text {st }}$ CENTURY

Vol. 77, No. 6, 2019

712

Table 2. Excerpts of clustered lesson planning II. learners.

The implementing teacher taught the mathematical concept 'probability' to Grade 7

\begin{tabular}{ll}
\hline Date & 03 February 2014 \\
\hline Place/School & Retsamaile P. School \\
\hline Time & $15 h 00$ \\
\hline Group facilitator/leader (+ contact details) & $\begin{array}{l}0714786509 \\
\text { JJ Motokenk }\end{array}$ \\
\hline Planning team (all teachers in the group implementing & $\begin{array}{l}\text { Ms. Mathe, Ms. Motokenk, Ms Haknka-Munzi, Fr. } \\
\text { Kodike, Mr. Kefane } \\
\text { teacher) }\end{array}$ \\
\hline Topic Selected & Probability \\
\hline Learners' prior knowledge & Counting figures \\
(Key ideas only) & Money \\
\hline
\end{tabular}

Define probability,

Content to be covered

Explain tally

(key ideas only)

Complete the tally table

Recording the results

Discuss results

\begin{tabular}{|c|c|}
\hline Intended Outcomes of the lesson & To be able to record the results on a tally table \\
\hline Resources to be used during the lesson & $\begin{array}{l}\text {-coin } \\
\text { - chalkboard } \\
\text {-worksheets } \\
\text { - textbook Premier LB page } 219 \\
\text { - } 220\end{array}$ \\
\hline $\begin{array}{l}\text { Lesson activities (what will learners do? What will the } \\
\text { teacher do?) } \\
\text { Adviser (any external invited participants) } \\
\text { Supporter: principal/ } \\
\text { Deputy Principal }\end{array}$ & $\begin{array}{l}\text {-the teacher explains how the experiment is going to } \\
\text { be done/ performs and asks questions }\end{array}$ \\
\hline
\end{tabular}

\section{Observational Activities}

The observational activities adopted by the teachers were guided by the Lesson Study Observational form. The observing teachers noted their observations every ten minutes describing what the implementing teachers and observing teachers were doing. A teacher observing the implementing teacher during a model lesson described what the teacher was doing as follows:

- Explanation was brief and straight to the point

- Gave real life examples

- Explained the activities or experiment to the learners and allowed them to record the results 
Loyiso C. JITA, Olugbenga Adedayo IGE. South African teachers' mathematical knowledge: Reflections from short learning intervention programme (SLIP)

- $\quad$ Teacher did not explain how tally marks work

- Struggled with the idea of fair and unfair coin

PROBLEMS

OF EDUCATION

IN THE $21^{\text {st }}$ CENTURY

Vol. 77, No. 6, 2019

713

- This teacher also described what the learners were doing as follows:

- Learners were listening attentively

- Each pair of learners was busy spinning a coin and recording the tally table.

Another teacher recorded her observations of the Mathematics teachers that taught probability to Grade 9 learners at Rankwe thus:

School: Rankwe Intermediate

Subject: Mathematics Grade nine (9):

Implementing Teacher: Pkohla G.A

Date: 28-03-2014

\section{Table 3. Excerpts of lesson study observations.}

\begin{tabular}{|c|c|c|}
\hline Time in minutes (every 10min) & $\begin{array}{l}\text { Describe what the teacher is } \\
\text { doing }\end{array}$ & $\begin{array}{l}\text { Describe what the learners are } \\
\text { doing }\end{array}$ \\
\hline 5 & $\begin{array}{l}\text { Introduction: she started by asking } \\
\text { questions? } \\
\text { What do you know about } \\
\text { probability? } \\
\text { The teacher explained: it is the } \\
\text { chance of getting something. }\end{array}$ & $\begin{array}{l}\text { One learner answered according } \\
\text { to his understanding }\end{array}$ \\
\hline 5 & $\begin{array}{l}\text { A teacher got into subject matter. } \\
\text { She showed learners a formular of } \\
\text { calculating probabilities. She took } \\
\text { a coin, showed two sides of the } \\
\text { coin, tail and the head. }\end{array}$ & $\begin{array}{l}\text {-learners changed fractions to } \\
\text { decimal and percentages. }\end{array}$ \\
\hline 10 & $\begin{array}{l}\text { Teacher's demonstration of } \\
\text { probability of getting one was } 1 / 6= \\
0,166=1 / 6 \times 100 / 1=100 / 6\end{array}$ & \\
\hline 10 & $\begin{array}{l}\text { She made questions of } 5 \text { blue } \\
\text { pens and } 15 \text { black pens. } \\
\text { What possibility of getting } 5 \text { pens. } \\
\text { She made a wheel spinner and let } \\
\text { the learner do the problem }\end{array}$ & $\begin{array}{l}\text { Learners calculations: } \\
5 / 20=0,25=1 / 4 \\
=25 \% \\
\text { Learners did the probabilities } \\
\text { without a problem. }\end{array}$ \\
\hline
\end{tabular}

The observing teacher inferred that:

Learners are able to do identifications and all the necessary calculations.

Post Observation Reflections

These are the post-observation reflections of the teachers that observed the implementing teachers in one of such selected schools (Rankwe). 
Loyiso C. JITA, Olugbenga Adedayo IGE. South African teachers' mathematical knowledge: Reflections from short learning intervention programme (SLIP)

OF EDUCATION

IN THE $21^{\text {st }}$ CENTURY

Vol. 77, No. 6, 2019

714

Table 4. Excerpts of post-observation observations reflections.

\begin{tabular}{|c|c|c|c|c|}
\hline & $\begin{array}{l}\text { What worked well } \\
\text { and why? }\end{array}$ & $\begin{array}{l}\text { What did not work } \\
\text { well and why? }\end{array}$ & $\begin{array}{l}\text { What were the } \\
\text { challenges? }\end{array}$ & $\begin{array}{l}\text { What should be } \\
\text { changed? }\end{array}$ \\
\hline \multirow[t]{2}{*}{$\begin{array}{l}\text { Pkohla, G.A. } \\
\text { (implementing } \\
\text { Teacher) }\end{array}$} & $\begin{array}{l}\text { Collected enough } \\
\text { resources that } \\
\text { helped the better } \\
\text { understanding of the } \\
\text { topic. } \\
\text { I let the leaners } \\
\text { manipulate the } \\
\text { resources and } \\
\text { calculate probability. }\end{array}$ & $\begin{array}{l}\text { Not all the learners } \\
\text { had a chance to } \\
\text { manipulate the } \\
\text { resources and go to } \\
\text { the board. }\end{array}$ & $\begin{array}{l}\text { Overcrowding in } \\
\text { the class and the } \\
\text { fear of going to the } \\
\text { board as they were } \\
\text { surprised to see } \\
\text { other teachers in the } \\
\text { class. }\end{array}$ & $\begin{array}{l}\text { Creation of classes with } \\
\text { reasonable numbers } \\
\text { of learners so that the } \\
\text { teacher can reach most of } \\
\text { the learners. }\end{array}$ \\
\hline & & & & $\begin{array}{l}\text { More time should be } \\
\text { allocated for Maths } \\
\text { periods. }\end{array}$ \\
\hline $\begin{array}{l}\text { Kefane T.S } \\
\text { (Observing } \\
\text { Teacher) }\end{array}$ & $\begin{array}{l}\text { Planning and teaching } \\
\text { aids. } \\
\text { Planning was well } \\
\text { done and worked } \\
\text { together with the } \\
\text { teaching aids. } \\
\text { Learners seemed to } \\
\text { be understanding and } \\
\text { were involved through } \\
\text { the lesson. }\end{array}$ & $\begin{array}{l}\text { Time was enough } \\
\text { for learners to show } \\
\text { their calculations } \\
\text { on the board and } \\
\text { in their workbooks } \\
\text { as feedbacks. Only } \\
\text { few learners were } \\
\text { able to }\end{array}$ & $\begin{array}{l}\text { Mathematics should } \\
\text { be allocated enough } \\
\text { time for learners } \\
\text { to have chance of } \\
\text { learning very well. }\end{array}$ & $\begin{array}{l}\text { Chance: } \\
\text {-creating of space and re- } \\
\text { arranging the groups. }\end{array}$ \\
\hline $\begin{array}{l}\text { Gakjalane } \\
\text { G.S. }\end{array}$ & $\begin{array}{l}\text { The educator was } \\
\text { well- prepared and } \\
\text { the lesson plan was } \\
\text { also good because it } \\
\text { was well structured } \\
\text { and understandable; } \\
\text { presentation was } \\
\text { good and learners } \\
\text { understood very well } \\
\text { what the educator } \\
\text { said. Teaching aids } \\
\text { were used in a good } \\
\text { manner. }\end{array}$ & $\begin{array}{l}\text { The learners } \\
\text { didn't take part } \\
\text { in manipulating } \\
\text { chalkboard due } \\
\text { to lack of time. } \\
\text { Grouping of } \\
\text { learners did not } \\
\text { allow them to take } \\
\text { part in using some } \\
\text { of the teaching } \\
\text { aids. }\end{array}$ & $\begin{array}{l}\text { Overcrowding of } \\
\text { the class was a } \\
\text { challenge } \\
\text { Some learners } \\
\text { were shy to do for } \\
\text { independent work } \\
\text { on the black board. } \\
\text { Time was also a } \\
\text { challenge. }\end{array}$ & $\begin{array}{l}\text { Creation of learning } \\
\text { space should meet the } \\
\text { favourable condition of } \\
\text { learners. } \\
\text { Groups of } 5-6 \text { learners } \\
\text { should be done to allow } \\
\text { them to take part in } \\
\text { activities. }\end{array}$ \\
\hline $\begin{array}{l}\text { Dlamni T.C. } \\
\text { (Observing } \\
\text { teacher) }\end{array}$ & $\begin{array}{l}\text { The lesson was well } \\
\text { prepared, and the } \\
\text { teaching was relevant } \\
\text { LTSM. }\end{array}$ & $\begin{array}{l}\text { The learning } \\
\text { space should } \\
\text { be created for } \\
\text { effective teaching } \\
\text { and learning }\end{array}$ & $\begin{array}{l}\text { Some of the learners } \\
\text { were afraid to come } \\
\text { to the front to solve } \\
\text { problems on a } \\
\text { chalkboard. }\end{array}$ & $\begin{array}{l}\text { The teacher should apply } \\
\text { group work and encourage } \\
\text { learners to work together } \\
\text { and help one another. }\end{array}$ \\
\hline $\begin{array}{l}\text { Tshabalah } \\
\text { G.S } \\
\text { (Observing } \\
\text { Teacher) }\end{array}$ & $\begin{array}{l}\text { The flow of the } \\
\text { lesson went well. The } \\
\text { educator was well } \\
\text { prepared and brought } \\
\text { to the classroom all } \\
\text { necessary teaching } \\
\text { aids. Learners could } \\
\text { see and touch the } \\
\text { teaching aids. }\end{array}$ & $\begin{array}{l}\text { The learners were } \\
\text { many in class and } \\
\text { the teacher could } \\
\text { get every learner } \\
\text { to manipulate or } \\
\text { touch the teaching } \\
\text { aids. }\end{array}$ & $\begin{array}{l}\text { The challenge was } \\
\text { overcrowding. }\end{array}$ & $\begin{array}{l}\text { The space in the } \\
\text { classroom must be } \\
\text { created so that groups are } \\
\text { formed, and each group } \\
\text { has the learning aids to } \\
\text { manipulate. } \\
\text { This can create the lasting } \\
\text { memory of what was } \\
\text { tough. }\end{array}$ \\
\hline
\end{tabular}


Loyiso C. JITA, Olugbenga Adedayo IGE. South African teachers' mathematical knowledge: Reflections from short learning intervention programme (SLIP)

PROBLEMS

OF EDUCATION

IN THE $21^{\text {st }}$ CENTURY

Vol. 77, No. 6, 2019

Teachers in another lesson study group in Botshabelo met and reflected on the lesson taught by a teacher in the group on the mathematical concept of probability, which was observed by other members of the group. The teachers individually commented as follows:

Table 5. Excerpts of post-observation observations reflections II.

\begin{tabular}{|c|c|c|c|c|}
\hline & $\begin{array}{l}\text { What worked well and } \\
\text { why? }\end{array}$ & $\begin{array}{l}\text { What did not work } \\
\text { well and why? }\end{array}$ & $\begin{array}{l}\text { What were the } \\
\text { challenges? }\end{array}$ & $\begin{array}{l}\text { What should be } \\
\text { changed? }\end{array}$ \\
\hline \multicolumn{5}{|l|}{$\begin{array}{l}\text { Ms. Mathe } \\
\text { (Implementing } \\
\text { Teacher) }\end{array}$} \\
\hline $\begin{array}{l}\text { Ms. Motokenk } \\
\text { (Observing } \\
\text { Teacher) }\end{array}$ & $\begin{array}{l}\text { Explanation was so } \\
\text { interesting because the } \\
\text { teacher was using real life } \\
\text { examples. } \\
\text { Learners were actively } \\
\text { involved }\end{array}$ & $\begin{array}{l}\text { The teacher failed } \\
\text { to control the class. } \\
\text { Because learners } \\
\text { were so excited when } \\
\text { they were performing } \\
\text { the events, spinning } \\
\text { the coin. }\end{array}$ & $\begin{array}{l}\text {-Learners were } \\
\text { so excited to the } \\
\text { extent that they } \\
\text { saw the activity } \\
\text { as an opportunity } \\
\text { to be noisy and } \\
\text { disruptive. }\end{array}$ & $\begin{array}{l}=\text { Next time when } \\
\text { learners perform } \\
\text { actively like this one } \\
\text { the teacher must } \\
\text { give them rule to } \\
\text { keep order. }\end{array}$ \\
\hline $\begin{array}{l}\text { Me. Haknka- } \\
\text { Munzi, } \\
\text { (Observing } \\
\text { Teacher) }\end{array}$ & $\begin{array}{l}\text { The explanation of the } \\
\text { term probability by the } \\
\text { teacher to learners. } \\
\text { The learners actively } \\
\text { participated to the asking } \\
\text { question activity }\end{array}$ & $\begin{array}{l}\text { The recording of } \\
\text { the Tallies to the } \\
\text { learners the teacher } \\
\text { failed to explain to } \\
\text { the learners. So, it } \\
\text { caused disruption to } \\
\text { the smooth running } \\
\text { of the activity. }\end{array}$ & $\begin{array}{l}\text { The class was a } \\
\text { little bit tense. } \\
\text {-time taken was } \\
\text { longer than the } \\
\text { planned time. } \\
\text { The observing } \\
\text { teacher took a } \\
\text { long time to fill in } \\
\text { the forms. }\end{array}$ & $\begin{array}{l}\text { Explain how tally } \\
\text { marks work, work } \\
\text { in groups than in } \\
\text { pairs. } \\
\text { Recording of tallies } \\
\text { on the tables. }\end{array}$ \\
\hline $\begin{array}{l}\text { Fr. Kodike } \\
\text { (Observing } \\
\text { Teacher) }\end{array}$ & $\begin{array}{l}\text { The explanation of } \\
\text { probability is brief and } \\
\text { supported by real life } \\
\text { examples. }\end{array}$ & $\begin{array}{l}\text { Failing to explain } \\
\text { how tally marks work. }\end{array}$ & $\begin{array}{l}\text { Time taken is } \\
\text { longer than } \\
\text { planned because } \\
\text { learners are } \\
\text { excited. }\end{array}$ & $\begin{array}{l}\text { Explained how tally } \\
\text { marks work with a } \\
\text { larger group of }\end{array}$ \\
\hline $\begin{array}{l}\text { Mr. Kefane } \\
\text { (Observing } \\
\text { Teacher) }\end{array}$ & $\begin{array}{l}\text { The teacher used simple } \\
\text { and useful teaching aids. } \\
\text { The teacher used the } \\
\text { correct daily life teaching } \\
\text { aids. }\end{array}$ & $\begin{array}{l}\text { They didn't know } \\
\text { how to toss the count } \\
\text { spin. }\end{array}$ & $\begin{array}{l}\text { The learners } \\
\text { didn't know how to } \\
\text { group the tally on } \\
\text { the tally table. } \\
\text { The learners } \\
\text { didn't know the } \\
\text { term probability }\end{array}$ & $\begin{array}{l}\text { They need thorough } \\
\text { practice of the term } \\
\text { probability. } \\
\text { They use the } \\
\text { probability on their } \\
\text { daily life activities. }\end{array}$ \\
\hline
\end{tabular}

\section{Discussion}

To understand the changes brought about by the intervention programme in teachers' mathematical knowledge, the discussion was arranged around pre-observational activities, observational activities, and post observation reflection. At this point, we discuss how the respondents transferred the knowledge gained from the SANRAL Chair in Science and Mathematics Education workshops, reflect on what the implementing Mathematics teachers have done well, and where the teachers need to improve in future lessons.

The findings of this study show that the selected teachers changed from a personalised or individual lesson planning to clustered lesson preparation. Jita and Mokhele (2012) described a 
Loyiso C. JITA, Olugbenga Adedayo IGE. South African teachers' mathematical knowledge: Reflections from short learning intervention programme (SLIP)

PROBLEMS

OF EDUCATION IN THE $21^{\text {st }}$ CENTURY Vol. 77, No. 6, 2019

716

cluster as 'a group of teachers' that collaborates on specific subject matter issues' (p. 5). These teachers worked together to plan the lesson, implement the planned lessons, and reflect on their instructional deliveries of the Mathematics lessons collectively planned. The clustered lesson planning that emerged from the current study confirmed Jita, Maree, and Ndlalane (2008)'s assertion that 'teachers from different schools are opportune to discuss their own work when they meet in a cluster' (p. 482). Jita et. al. (2008) further asserted that feedbacks received from the cluster meetings enable teachers to develop trust and confidence in their colleagues that culminate into sharing and exchanging of aide-memoire on classroom practice. It is also noted from the sample lesson plans included in the portfolio of evidence submitted by the teachers that there was a transition from the conventional lesson plan to an activity-based lesson plan. The inclusion of action activities that involved learners tossing a coin, recording the outcomes on a tally table that enabled the learners to find the frequency change learning landscape created by the teachers in the grade Mathematics classrooms. The emergence of an activitybased lesson plan from the selected teachers 'clustered' interactions confirmed Lijanporn and Khalisang (2015)'s assertion that 'an activity-based learning should have essential features such as motivation and experience, knowledge and practice, feedback and evaluation' (p. 1709). These four essential features highlighted by Lijanporn and Khalaisang (2015) were evident in the model lesson plans included in the portfolio of evidence submitted by the teachers that participated in the study.

The observational activities enabled the teachers in each cluster to collaboratively assess each Mathematics lesson taught by their colleagues. This act exhibited by teachers in the cluster networks was described by Jita and Mokhele (2014) as the 'process' benefits of clustering. The findings from observational activities describe the utopian Mathematics lessons that emanated from the improved mathematical know-how of teachers. It will be appropriate to call the classrooms that emerged in this study 'the ideal Mathematics classroom'. It is ideal because a teacher implemented the lesson planned through clustering, other teachers in the cluster observed the lesson to provide information on the worth of the instructional delivery carried out by their colleagues. The evaluating teachers also learnt the pitfalls peculiar to the delivery of such a concept in Mathematics, and techniques of preventing or arresting such a trend in their lesson delivery.

A teacher that observed a Grade 9 Mathematics class at Rankwe intermediate school where the Mathematics teacher taught 'probability' declared that learners could do the identification and all the necessary calculations in this excerpt:

The way this teacher deconstructed the classroom that emerged from the clustering lesson implementation exemplified a 'collaborative' Mathematics classroom. It is collaborative because the Mathematics classroom encouraged teacher to teacher observation, teacher to student interaction, and learner to learner involvement in solving the mathematical problems related to probability.

The clustering teacher engaged in post-observation reflection after each Mathematics lesson. Zeichner (2008) credits the emergence of post-observation reflection to Shulman and colleagues at Michigan State University and states that it is aimed at developing teachers' capacities to make intelligent decisions to achieve educational goals. The clustering teachers' post-observation reflected on what worked well and why? What did not work well and why? What were the challenges? And what should be changed?

The use of appropriate instructional materials to teach probability emerged as the dominant theme in the clustering teachers post observation reflection on what worked well. The dimensional use of instructional materials by the clustering teachers is in line with Firmender, Gavin and McCoach (2014) that the mathematical community is the classroom where learners 
Loyiso C. JITA, Olugbenga Adedayo IGE. South African teachers' mathematical knowledge: Reflections from short learning intervention programme (SLIP)

can engage in both verbal and written forms of mathematical communication. Firmender et al. (2014) further assert that a teacher that implements instructional practices as exhibited by the clustering teachers in this study listens to the ideas of students and challenges such students to peoples' rational basis for such ideas. The reason why the use of instructional insufficient time allocated to Mathematics lesson thematically emerged as a primary factor of what did not work well.

Materials worked well for the teachers because learners could see and touch the instructional materials. The implementing teachers used the instructional materials in an interactive manner which enabled the learner to carry out mathematical calculations on the chalkboard. One of the observing clustering teachers responded to the question on what worked well and why by stating that:

Planning and teaching aids. Planning was well done and worked together with the teaching aids. Learners seemed to be understanding and involved throughout the lesson.

Insufficient instructional time allocated to Mathematics in the selected schools thematically emerged primarily as what did not work well. Cattaneo, Oggenfuss, and Wolter (2016) in comparing the efficiency of an additional hour of instruction for learners with varied academic abilities and school environment in Switzerland discovered that an hour of instruction might have a common productivity for all subjects but, with a possibility that different students profit differently from extra instructional time from the descriptive analysis those scholars applied to the data sets they used. A teacher that observed the delivery of the clustered-planned Mathematics lesson in one of the selected schools illustrated a point that justified that some of the learners might benefit from extra instructional time in these excerpts:

Time was not enough for learners to show their calculations on the board and in their workbooks as feedbacks. Only few learners were able to.

Another teacher in the observing clustering team stated that:

The learners didn't take part in manipulating the chalkboard due to lack of time.

These quotations from the clustering teachers show the importance of allocating adequate time for Mathematics lessons. The observations of these clustering teachers confirm the findings of Baker, Fabrega, Galindo and Mishook (2004) in their analysis of three global datasets of instructional time in four curricular subjects namely Programme for International Student Assessment (PISA), TIMSS, and International Study of Civic Education (CIVICS) 2000, and 1999 respectively. Baker et. al. (2004) discovered that Macedonia and South Africa devoted the least time for instructional delivery in Mathematics, while Italy and Denmark had approximately five hours of Mathematics classes per week. Baker et al. (2004) further discovered students in a country like Greece received 4.8 hours of weekly Mathematics classes, New Zealand and Iceland afforded learners approximately 4 hours of Mathematics weekly instructions, while other countries in the Schengen area did not devote up to three hours for Mathematics classes per week.

Researchers should be aware that despite the benefits of reconstructing teachers' mathematical knowledge through clustering, there are challenges inherent in it. Amosun and Ige (2014) state that 'all coins usually have two sides', overcrowded classes and learners' diffidence emerged as the challenges that confronted the clustering teachers in the implementation or delivery of the model Mathematics lessons. One of the clustered teachers stated that:

\begin{tabular}{|l} 
PROBLEMS \\
OF EDUCATION \\
IN THE 21 $1^{\text {st }}$ CENTURY \\
Vol. 77, No. 6,2019 \\
\hline 717
\end{tabular} 
Loyiso C. JITA, Olugbenga Adedayo IGE. South African teachers' mathematical knowledge: Reflections from short learning intervention programme (SLIP)

PROBLEMS

OF EDUCATION

IN THE $21^{\text {st }}$ CENTURY

Vol. 77, No. 6, 2019

718

Overcrowding of the classroom was a challenge. Some learners are shy to do individual work on the black board. Time factor was also a challenge.

The challenge peculiar to the utilisation of knowledge acquired by the clustering teachers from the short learning intervention programme is further encapsulated in this narrative:

Some of the learners were afraid to come to the front to solve problems on a board. Overcrowding in the class and fear of going to the board as they were surprised to see other teachers in the class when I am teaching.

This narrative justifies the inclusion of strategies to control overcrowded classes and support timid learners in Mathematics classes in clustering lesson plans.

In stating what should be changed in using the clustering teaching approach that emanates from a short learning intervention programme by teachers, a teacher commented on those things that must be changed for effective clustering instructional delivery in Mathematics:

The space in the classroom must be created so that groups are formed, and each group has the learning aids to manipulate. This can create the lasting memory of what was tough.

The teacher that implemented one of the Mathematics lessons also proposed changes in her post-observation reflection. As the teacher commented:

Creation of classes with reasonable number of learners so that the teacher can reach most of the learners. More time should be allocated for Maths periods.

From the reflections of this implementing teacher, it is evident that instructional periods will become inadequate when teachers' mathematical knowledge is improved using an intervention programme. It should be noted that the implementing teacher taught the class she is suggesting improvement to before her involvement in the short learning programme. From the discussion, clustering teachers must pay attention to the following when implementing a Mathematics lesson that is found on knowledge gained from an intervention programme:

1. The use of instructional materials which are essential to the mastery of the mathematical concepts being taught.

2. Use of enough instructional time to teach the mathematical concepts.

3. Grouping of learners in a crowded classroom.

These emerging themes confirmed process benefits by Jita and Mokhele (2014) which constituted the values of teamwork, instructional guidance, and pedagogical leadership. Fischer, Borowski, and Tepner (2012) stated that Shulman (1986) described pedagogical knowledge as classroom knowledge of general principles pertaining to organisation and management) (Recast this. It's confusing). It could be inferred from Shulman's (1986) assertion that Jita and Mokhele (2014) educational leadership connotes leadership in general principle of classroom organisation and supervision.

The benefits of teaching observation are adequately documented in literature (BultermanBoss, Terwel, Verloop \& Wardekker, 2002). Bulterman-Bos et al. (2002) affirmed that informal assessment such as observation enables teachers to become acquainted will their learners. The observational activities carried out in this study enable teachers to get to know their colleagues. Jita and Mokhele (2014) establish that the networks emanating from observational activities that enable teachers to communicate share and address issues, observe each other's lesson, and develop expertise in multi-faceted aspects of teaching practice. 
Loyiso C. JITA, Olugbenga Adedayo IGE. South African teachers' mathematical knowledge: Reflections from short learning intervention programme (SLIP)

Khachatryan (2015) stated that in her professional roles as a researcher, teaching leader and teacher, it was discovered that teachers desire eagerly qualitative feedback on their teaching practice, which they rarely receive. The Short Learning Intervention programme was put together to meet the professional needs of in-service teachers discovered by Khachatryen (2015). Klette and Blistad-Balas (2017) note the benefits of teaching observation and further posit that it affords teachers opportunity to observe each other; school leaders such as principals, viceprincipals can observe their teachers, and teacher educators and teacher mentors can observe student teachers.

Despite the immense benefits of using teaching observation as a tool for teachers' professional development, Klette and Blikstad-Balas (2017) reiterated Stuhlman, Hamre, Downer, and Pinnta (2010)'s warning on the use of unstandardized, informal and un-validated instruments for such a programme. This intervention programme used a standardized instrument to report the post-teaching observations of the participants which involved the implementing and observing teachers).

\section{Conclusions}

Consequent on the outcomes of this research, the teaching clusters that emerged from the SANRAL Chair Science and Mathematics Education's short learning intervention programme were formed by the teachers themselves. The non-attachment of the teaching clusters to any official organ of educational authority protected them from bureaucratic ethos and allowed the teachers to focus on the utilisation of knowledge acquired from the intervention programme to improve instructional delivery in Mathematics classes in the schools that nominated them for the programme. In conclusion, despite the evidences emanating from this research on the benefits of using intervention programmes for Mathematics teachers, further educational fact-finding is proposed to juxtapose the findings reported in this research in other teaching clusters across the world. The teacher clusters reported in this study are limited to South Africa. Educational researchers should exercise caution in generalising the findings to other teacher clusters in other countries of the world. However, the teacher clusters notified the School Management Team (SMT) in schools selected for the implementation of the study. This research is one of the earliest efforts on training mathematics teachers in South African public schools, and it has contributed to current knowledge on the improvement of instructional practices in mathematics. It is recommended that future educational researchers should replicate this type research in science, technology, and engineering subjects to build the capacity of teachers for optimal lesson delivery.

\section{References}

Amosun, P.A., \& Ige, O.A. (2014). The Nigeria action cyber-crime prevention programme. In L. Gómez Chova et al. (Eds.), Rethinking learning in a connected age. INTED 2014 Proceedings, IATED Academy, Valencia, Spain.

Baker, D. P., Fabrega, R., Galindo, C., \& Mishook, J. (2004). Instructional time and national achievement: Cross-national evidence. Prospects: Quarterly Review of Comparative Education, 34(3), 311334.

Bell, M. (2001). Supported reflective practice: A programme of peer observation and feedback for academic teaching development. International Journal for Academic Development, 6(1), 29-39.

Bell, M. (2002). Peer observation of teaching in Australia. Learning and Teaching Support Network, Generic Centre. Retrieved from www.heacademy.ac.uk/resources/detail/.

Bulterman-Bos, J., Verloop, N., Terwel, J., \& Wardekker, W. (2003). Reconciling the pedagogical goal and the measurement goal of evaluation: The perspectives of teachers in the context of national standards. Teachers College Record, 105(3), 344-374.

$\mid$\begin{tabular}{l} 
PROBLEMS \\
OF EDUCATION \\
IN THE 21 $1^{\text {st }}$ CENTURY \\
Vol. 77, No. 6, 2019 \\
\hline 719
\end{tabular} 
Loyiso C. JITA, Olugbenga Adedayo IGE. South African teachers' mathematical knowledge: Reflections from short learning intervention programme (SLIP)

PROBLEMS

OF EDUCATION IN THE $21^{\text {st }}$ CENTURY Vol. 77, No. 6, 2019

720

Cattaneo, M. A., Oggenfuss, C., \& Wolter, S.C. (2017). The more, the better? The impact of instructional time on student performance. Education Economics, 25(5), 433-445. https://doi.org/10.1080/096 45292.2017.1315055.

Engin, M. (2016). Enhancing the status of peer observation through the scholarship of teaching and learning. International Journal for Academic Development, 21(4), 377-382, https://doi.org/10.10 80/1360144X.2016.1225576.

Firmender, J. M., Gavin, M. K., \& McCoach, D. B. (2014). Examining the relationship between teachers' instructional practices and students' mathematics achievement. Journal of Advanced Academics, 25(3), 214-236. https://doi.org/10.1177\%2F1932202X14538032.

Fischer H. E., Borowski A., \& Tepner, O. (2012). Professional knowledge of science teachers. In B. Fraser, K. Tobin \& C. McRobbie (Eds.), Second international handbook of science education (pp. 435-448). New York: Springer.

Free State Department of Education (2017). Department of Education Province of Free State vote no. 6 annual report 2017/2018 financial year. Retrieved from https://provincialgovernment.co.za/ department annual/630/2018-free-state-education-annual-report.pdf.

Glaser, B., \& Strauss, A. (1967). The discovery of grounded theory. Chicago: Aldine.

Jita, L. C., Maree, J. G., \& Ndlalane, T. C. (2008). Lesson study (Jyugyo Kenkyu) from Japan to South Africa: A science and mathematics intervention program for secondary school teachers. In Atweh B. et al. (Eds), Internationalisation and globalization in mathematics and science education (pp.465-486). Dordrecht, Springer.

Jita, L. C., \& Mokhele, M. L. (2012). Institutionalising teacher clusters in South Africa: Dilemmas and contradictions. Perspectives in Education, 30(2), 1-11.

Jita, L. C., \& Mokhele, M. L. (2014). When teachers cluster work: Selected experiences of South African teachers with the cluster approach to professional development. South African Journal of Education, 34(2), 1-15.

Khachatryan, E. (2015). Feedback on teaching from observations of teaching: What do administrators say and what do teachers think about it? NASSP Bulletin, 99(2) 164-188.

Klette, K., \& Blikstad-Balas, M. (2017). Observation manuals as lenses to classroom teaching: Pitfalls and possibilities. European Educational Research Journal, 17(1), 129-146. https://doi.org/10.11 77\%2F1474904117703228.

Labuschagne, S. E. (2016). Mathematical knowledge for secondary school teaching: Exploring the perspectives of South African research mathematicians. Magister Educationis dissertation submitted to North-West University, South Africa. Retrieved from https://dspace.nwu.ac.za/ bitstream/handle/10394/21081/Labuschagne_SE_2016.pdf?sequence=1\&isAllowed=y.

Lijanporn, S., \& Khlaisang, J. (2015). The development of an activity-based learning model using educational mobile application to enhance discipline of elementary school students. Procedia Social and Behavioral Sciences, 174, 1707-1712. https://doi.org/10.1016/j.sbspro.2015.01.825.

McGrath, J. I. (2015). The People and the Policy: The Possibilities and Limitations of Current Supervisory Appraisal Practices for Experienced Secondary Teachers in Ontario. A thesis submitted in conformity with the requirements for the degree of Doctor of Philosophy Department of Curriculum, Teaching and Learning Ontario Institute for Studies in Education University of Toronto. Retrieved from https://tspace.library.utoronto.ca/.

Martin, G. A., \& Double, J. M. (1998). Developing higher education teaching skills through peer observation and collaborative reflection. Innovations in Education \& Training International, 35(2), 161-170. https://doi.org/10.1080/1355800980350210.

Organisation for Economic Cooperation and Development. (2014). Indicator D1: How much time do students spend in the classroom? In Education at a Glance 2014: OECD Indicators, OECD Publishing. http://dx.doi.org/10.1787/888933119530.

Rees, E. L., Davies, B., \& Eastwood, M. (2015). Developing students' teaching through peer observation and feedback. Perspectives on Medical Education, 4, 268-271. https://doi.org/10.1007/s40037015-0213-9.

Reddy, V., Prinsloo, C., Arends, F., Visser, M., Winnaar, L., Feza, N., Rogers, S., Janse van Rensburg, D., Juan, A., Mthethwa, M., Ngema, M., \& Maja, M. (2012). Highlights from TIMSS 2011: The South African perspective. (Commissioned by the Department of Basic Education, December). Human Sciences Research Council, Pretoria, South Africa. Retrieved from http://www.hsrc.ac.za/ en/research-data/view/6480. 
Loyiso C. JITA, Olugbenga Adedayo IGE. South African teachers' mathematical knowledge: Reflections from short learning intervention programme (SLIP)

PROBLEMS

OF EDUCATION

IN THE $21{ }^{\text {st }}$ CENTURY

Vol. 77, No. 6, 2019

Rossi, J., \& Stuart, A. (2007). The evaluation of an intervention programme for reception learners who experience barriers to learning and development. South African Journal of Education, 27(1), 139154.

Shulman, L.S. (1986). Those who understand: Knowledge growth in teaching. Educational Researcher, 15(2), 4-14.

Shulman, L.S. (1987). Knowledge and teaching: Foundations of the new reform. Harvard Educational Review, 57(1), 1-23.

Shulman, L. S. (2000). From Minsk to Pinsk: Why a scholarship of teaching and learning. Journal of Scholarship of Teaching and Learning, 1(1), 48-53.

Stuhlman, M. W., Hamre, B. K., Downer, J. T., \& Pianta, R. C. (2010). Why should we use classroom observation? Centre for Advanced of Teaching and Learning, University of Virginia. Retrieved from http://curry.virginia.edu/uploads/resourceLibrary/CASTL_practioner_Part1_single.pdf.

Taylor, N. (2008). What's wrong with South African schools? Retrieved from http://www.eranet.co.za/ zenex.

Thomson, K., Bell, A., \& Hendry, G. (2015). Peer observation of teaching: the case for learning just by watching. Higher Education Research \& Development, 34(5), 1060- 1062.

Venkat, H., \& Spaull, N. (2015). What do we know about primary teachers' mathematical content knowledge in South Africa? An analysis of SACMEQ 2007. International Journal of Educational Development, 41, 121-130. https://doi.org/10.1016/j.ijedudev.2015.02.002.

Zeichner, K. M. (2008). A critical analysis of reflection as a goal for teacher education. Educação \& Sociedade, 29(103), 535-554. https://dx.doi.org/10.1590/S0101-73302008000200012.

Received: August 20, 2019

Accepted: November 15, 2019

\begin{tabular}{|ll}
\hline Loyiso C. Jita & $\begin{array}{l}\text { Dean and SANRAL Chair in Science and Mathematics Education, Faculty } \\
\text { of Education, P.O. Box 339, Bloemfontein 9300, Republic of South Africa. } \\
\text { E-mail: jitalc@ufs.ac.za }\end{array}$ \\
\hline $\begin{array}{l}\text { Olugbenga Adedayo Ige } \\
\text { (Corresponding author) }\end{array}$ & $\begin{array}{l}\text { Lecturer/Researcher, Faculty of Education, University of the Free State, } \\
\text { QwaQwa Campus, Phuthadithaba, 9866, Republic of South Africa. } \\
\text { E-mail: IgeOA@ufs.ac.za }\end{array}$
\end{tabular}

